\title{
Totally impermeable film retains fumigants, allowing lower application rates in strawberry
}

by Steven A. Fennimore and Husein A. Ajwa

\section{The California strawberry industry is} highly dependent on soil fumigation to control soil pests and maintain high productivity. Plastic films are used to hold fumigants in the soil at the doses needed to control pests and to prevent the loss of fumigant. Totally impermeable film (TIF) was compared to standard film (STD) for the retention of soil fumigants. 1,3-dichloropropene plus chloropicrin concentrations under TIF were $46 \%$ to $54 \%$ higher than under standard film, and higher fumigant concentrations under TIF were correlated with higher strawberry fruit yields and better weed control. The results suggest that to achieve fruit yield and weed control similar to methyl bromide and chloropicrin, 33\% less 1,3dichloropropene plus chloropicrin is needed under TIF than standard films.

$\mathrm{T}$ he California strawberry industry produces about $85 \%$ of the strawberries grown in the United States, on 37,000 acres, with a value of $\$ 1.5$ billion in 2008 (ERS 2009). To control soilborne diseases and weeds, California strawberry fields have long been fumigated with methyl bromide (MB) plus chloropicrin (Pic). However, methyl bromide is being phased out as an ozone-depleting substance under the Montreal Protocol (USDS 2009), an international treaty. Currently, some California strawberries can still be treated with methyl bromide under a critical-use exemption, subject to annual review by parties to the Montreal Protocol.

Alternative fumigants permitted for use in California strawberries are 1,3-dichloropropene (1,3-D), chloropicrin and, as of December 2010, methyl iodide. About $81 \%$ of California strawberries are grown in soils that were previously treated with chloropicrin (Pic), while 30\%

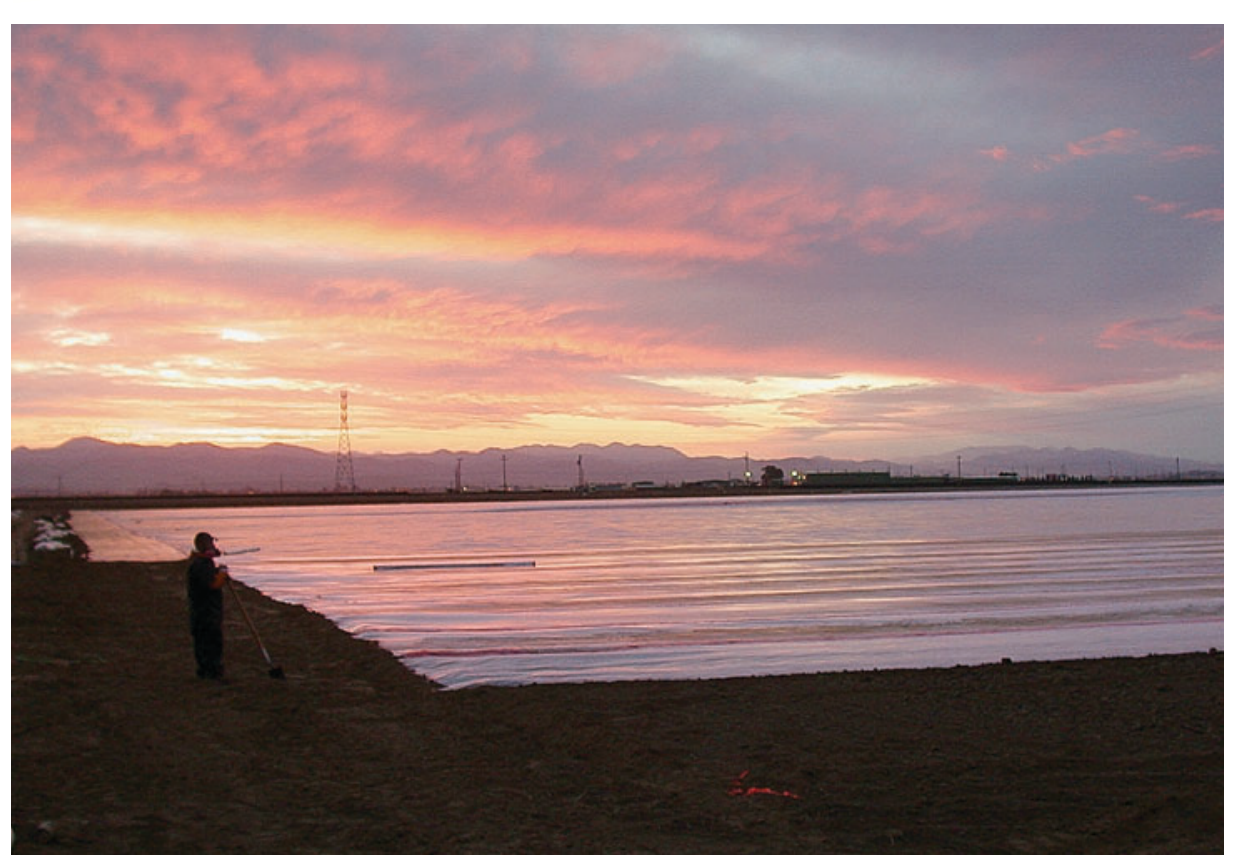

About $80 \%$ of California strawberry fields, such as these in Santa Maria, are treated with soil fumigants prior to planting. Plastic tarps are applied to prevent leakage of the fumigants.

are also fumigated with 1,3-D and 43\% with methyl bromide (CDPR 2008).

Since soil treatments began in the 1960s, entire fields have been covered with polyethylene film to hold in the fumigant at concentrations needed to kill soil pests (called "flat fumigation") (Wilhelm and Paulus 1980). More recently, a sizable portion ( $45 \%$ to $55 \%$ ) of strawberry acreage has been treated with fumigants applied to beds via the drip irrigation system (Ajwa et al. 2002; USDS 2009).

The major alternatives to methyl bromide, 1,3-D and chloropicrin, are heavily regulated. The transition away from methyl bromide to alternatives has been complicated by regulations aimed at protecting workers and others from exposure to fumigants. In California, 1,3-D use per 36-square-mile township is limited to 90,250 pounds, called a "township cap," which severely limits its availability in key strawberry production areas (Carpenter et al. 2001). The recent criticaluse nomination for strawberry (allowing methyl bromide use) indicates that "township caps currently limit the use of 1,3-D on $40 \%$ to $62 \%$ of total strawberry land" (USDS 2009). In other words, methyl bromide use continues in California because restrictions on alternative fumigants leave few options.

Among the reasons that fumigants are so heavily regulated in California is that they are classified as volatile organic compounds (VOCs). Alternative fumigants such as 1,3-D are released into the air and, after reacting with nitrogen oxides, can convert to form ground-level ozone - a harmful air pollutant (Gao 2009; Segawa 2008). Regulations have been developed to reduce the contribution of fumigants to ozone formation, which, for example, has seriously affected the use of fumigants in Ventura County, a key strawberry production area.

\section{Fumigants and barrier films}

Gas-impermeable films can minimize fumigant emissions, increase their retention over time and reduce the amount of fumigant needed for effective pest control (Gamliel et al. 1998; Minuto et al. 1999; Wang et al. 1999). The use of virtually

Originally published online only.

http://californiaagriculture.ucanr.org/

landing page.cfm?article=ca.E.v065n04p211\&fulltext=yes DOI: 10.3733/ca.E.v065n04p211 
impermeable film (VIF) can greatly reduce fumigant emissions and enhance their distribution in soil, in comparison with conventional polyethylene films or uncovered soil (Chellemi and Mirusso 2002; Nelson et al. 2001). VIF differs from traditional high-density polyethylene tarps in that it has additional gasimpermeable layers, such as nylon or polyaminides, between the polyethylene layers (Wang et al. 1997).

Fumigant concentrations of 1,3-D and chloropicrin were higher under VIF than low-density polyethylene (LDPE) tarp, 1 to 4 days after drip fumigation (Desaeger and Csinos 2005). The improved retention of fumigants under VIF also provides more opportunity for them to degrade in the soil rather than be released into the atmosphere (Wang and Yates 1998). A number of researchers have found that VIF as a tarp can reduce the amount of 1,3-D plus chloropicrin needed for effective soil disinfestations by $50 \%$ (De Cal et al. 2004; Medina et al. 2006; Porter et al. 2006). Santos et al. (2005, 2007) found that reducing methyl bromide plus chloropicrin rates by one-half under VIF controlled nutsedge similarly to the fullrate of 350 pounds per acre applied under standard films.

A relatively new barrier, totally impermeable film (TIF), has been shown to apply easily and retain fumigant better than VIF (Ajwa 2008; Chow 2008). TIF is a fivelayer film with two thin ethylene vinyl alcohol layers embedded in three layers of standard polyethylene film (Chow 2008).

Our studies evaluated the compatibility of TIF and standard films with the two major fumigant application methods for strawberry, broadcast fumigation and chemigation. The primary objective was to compare fumigant retention under TIF and standard film. Secondary objectives were to measure the effects on strawberry fruit yield and weed control.

\section{TIF field evaluations}

Broadcast fumigation trial (2007). We compared the retention of methyl bromide plus chloropicrin under TIF and standard films at a commercial farm near Salinas in 2007. The soil was a Chualar sandy loam. Methyl bromide $57 \%$ plus chloropicrin $43 \%$ (weight per weight $[\mathrm{w} / \mathrm{w}]$ ) and 1,3-D $61 \%$ plus chloropicrin $35 \%(\mathrm{w} / \mathrm{w})$ (trade name Telone C35), both at 350 pounds per acre, were applied by a commercial

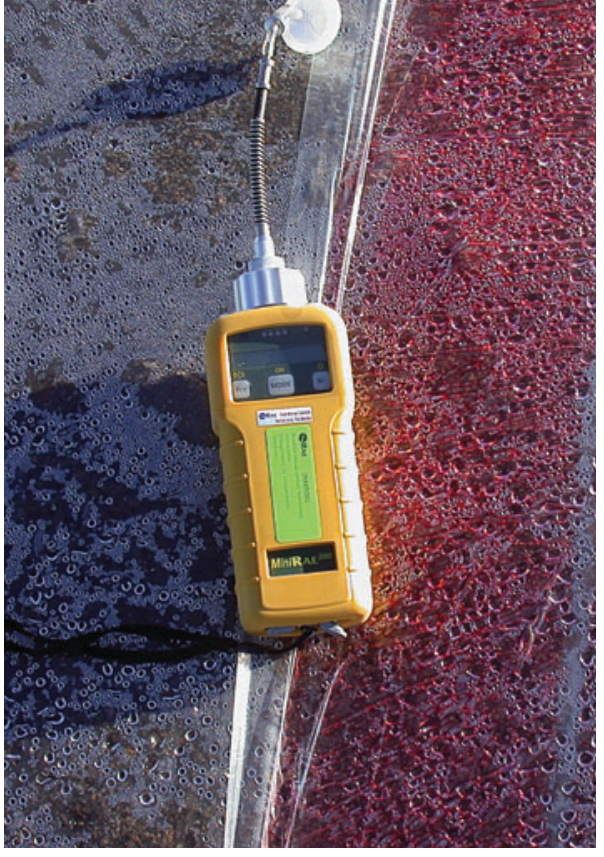

A meter was used to measure volatile organic compounds (VOCs), which can react with nitrogen oxides to form air pollutants.

applicator (TriCal, Hollister, CA) on Oct. 15, 2007. As the fumigant was applied, it was immediately tarped by 13 -foot-wide standard film (STD) (TriCal, 1-mil-thick [1 mil =1/1000th inch] high-density polyethylene) or 13-foot-wide TIF (Raven, Sioux Falls, SD; 1.4-mil thickness).

The plots were 280 feet long and 33 feet wide to allow for three passes, each 11 feet wide, of the application tractor. The films were 13 feet wide overall with 1 foot on the leading edge used to anchor the film in the soil and 1 foot on the trailing edge used to glue to the leading edge of the previous pass, creating a 1-foot overlap. Hence, the applied film is like rows of overlapped roofing shingles. The proprietary glue used by the commercial applicator adhered to the TIF film and held it in place without incident.

Each treatment was replicated two times and arranged in a randomized complete block design. Fumigant concentrations under the tarp were monitored with a MiniRae VOC meter (Rae Systems, San Jose, CA) at 3, 27, 51, 76, 97, 120 and 166 hours after application. The MiniRae VOC meter uses a photo ionization detector to measure the concentrations of volatile compounds such as fumigants. Fumigant samples were taken from airspace between the soil surface and the tarp at three random locations near the center of the plots. The film was cut and removed 192 hours after application.

The field was then prepared for strawberry planting by the installation of 52-inch-wide raised beds with two drip irrigation lines per bed. 'Albion' strawberry was transplanted on Nov. 11, 2007. Strawberry fruit were harvested from two 40-plant sample stations per plot from April 18 to Sept. 1, 2008, and fruit were sorted into marketable and cull fruit by a trained crew. Weeds were sampled from two 125-square-foot sample areas on Feb. 15, April 28 and July 8, 2008.

Chemigation trial (2008). In 2008, we evaluated TIF at the USDA Agricultural Research Service farm on Spence Road near Salinas. The soil was a Chualar sandy loam. We injected 1,3-D 35\% plus chloropicrin $60 \%$ plus an emulsifier $5 \%$ (w/w) (trade name Pic-Clor 60) through the drip irrigation system (chemigation) on Oct. 21, 2008, at 50, 100, 200, 300 and 400 pounds per acre, under both standard (TriCal, 1 mil) and TIF (Raven, Sioux Falls, SD; 1.4 mil) film (Ajwa et al. 2002).

Briefly, the fumigants were injected in a closed system directly from nitrogenpressurized cylinders and metered into irrigation water with a flow meter (Key Instruments, Trevose, PA; McMaster-Carr Supply, Los Angeles, CA). A static mixing device (TAH Industries, Robbinsville, NJ) was installed at the point of injection to mix fumigants with irrigation water before distribution via the drip irrigation system. A backflow prevention device (Amiad Filtration Systems, Oxnard, CA) was used to prevent contamination of the water source. An emulsifiable formulation of methyl bromide $57 \%$ plus chloropicrin $43 \%$ (w/w) was applied on Oct. 29, 2008, at 350 pounds per acre, also through the drip irrigation system.

Each treatment was replicated four times, and the trial was arranged in a randomized complete block design. Plot sizes were a single 52-inch-wide by 75 -foot-long bed. Fumigant concentrations under the tarp were sampled at one location near the plot center with a MiniRae VOC meter as described above, at 3, 8, 24, 48, 72, 96, 144, 192, 240 and 336 hours after application. The MiniRae meter was calibrated with known concentrations of 1,3-D and chloropicrin prior to each sampling.

The plastic films were left on the beds for the length of the strawberry season. Before transplanting strawberries, planting holes were punched in the bed, and 'Albion' strawberry was transplanted by hand into all plots on Nov. 24, 2008. Visual crop injury was estimated on Jan. 6, 2009, using a scale of $0=$ safe to $10=$ dead. On 
March 10, 2009, diameters were measured on 20 plants per plot. Fruit were harvested from 50 sample stations in each plot once or twice weekly as needed from March 30 until Oct. 30, 2009. Fruit were graded as described in the 2007 trial.

Weed measurements. Weed densities were measured in 2007 and 2008. In 2008, nylon bags containing yellow nutsedge tubers and weed seeds (common chickweed, prostrate knotweed, little mallow and common purslane) were buried in each plot before the fumigant application, at a depth of 6 inches. These species were evaluated because they represent a range of susceptibility to fumigants from difficult (nutsedge and little mallow), to intermediate (knotweed), to easy (chickweed and purslane). Little mallow and chickweed are common in strawberry.

Weed seeds were retrieved 2 weeks after the methyl bromide plus chloropicrin application, and their viability was determined. The yellow nutsedge was planted in potting soil and placed in an illuminated growth chamber at $85^{\circ} \mathrm{F}$ for 4 weeks. Weed seed viability was determined using tetrazolium assays. Weed density ratings were measured in 125-square-foot sample areas on the bed tops, on Feb. 15, April 28 and July 8, 2008 (2007 trial), and Dec. 11, 2008, and Feb. 3 and March 17, 2009 (2008 trial).

Statistical analysis. The data was subjected to analysis of variance in SAS v. 9.1 (SAS Institute, Cary, NC), and Duncan's multiple range test was used for mean separation for all data at the 5\% significance level. Weed seed and yellow nutsedge tuber survival data were analyzed to evaluate the effects of fumigant rate, film, and the interaction between rate and film. Linear contrasts were used to compare weed seed survival under the TIF and standard films using SAS PROC GLM. To determine if there was any correlation between strawberry fruit yield and fumigant concentrations, the 2008 data was tested using the SAS PROC CORR routine. Fumigant concentration and weed density data (Salinas 2008 only) were subjected to nonlinear regression analysis using Sigma Plot v. 11 (SPSS, Chicago, IL).
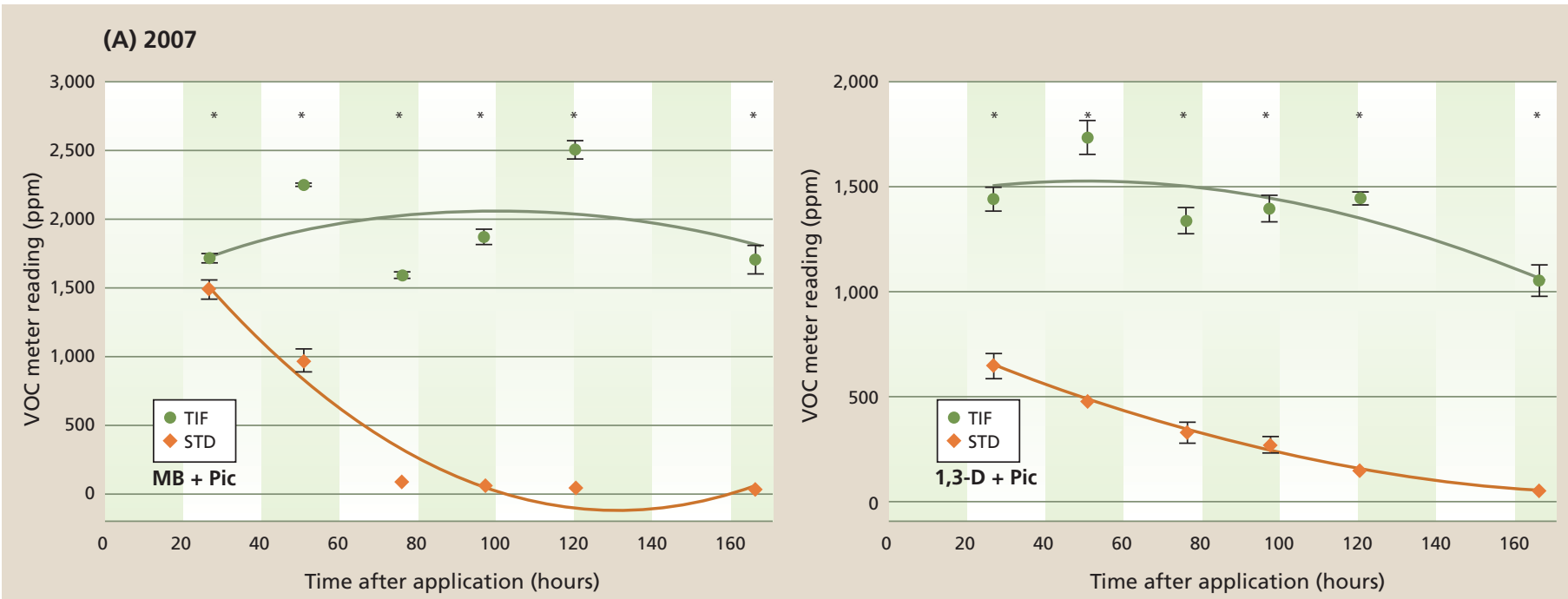

(B) 2008
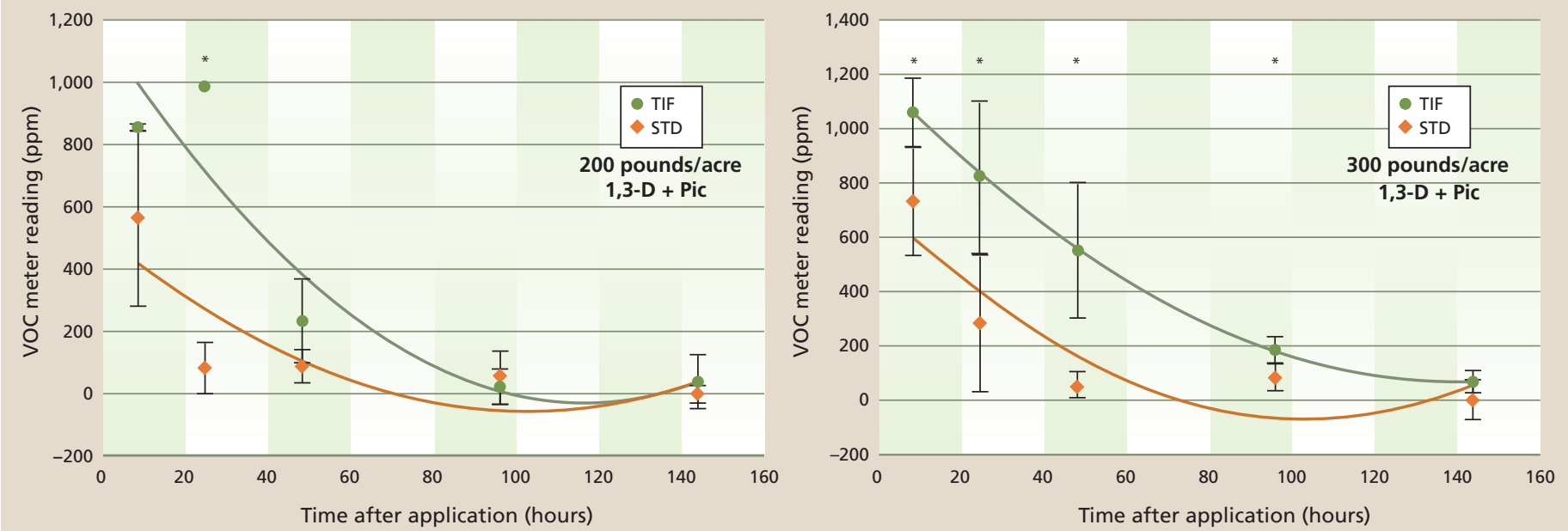

Fig. 1. (A) Methyl bromide plus chloropicrin (MB + Pic) (left) and 1,3-D plus chloropicrin (Pic) (right) VOC meter readings under totally impermeable (TIF) and standard (STD) films at 27, 51, 76, 97, 120 and 166 hours after application, Salinas, 2007; and (B) VOC meter readings for 1,3-D plus chloropicrin under TIF and STD films at 200 pounds (left) and 300 pounds (right) per acre at 8, 24, 48, 96 and 144 hours after application, Salinas, 2008. Lines are predicted values of nonlinear regression analysis using the polynomial function. Asterisks indicate significantly higher fumigant dose under TIF than STD according to Duncan's multiple range test at $P=0.05$. Error bars are standard error of the mean. 


\section{Film effectiveness}

2007 trial. At Salinas in 2007, methyl bromide plus chloropicrin and 1,3-D plus chloropicrin were both retained for 0 to 166 hours at significantly higher concentrations under TIF than under standard film (fig. 1A). Average strawberry fruit yields for 1,3-D plus chloropicrin were 0.77 (TIF) and 0.71 (STD) pounds per plant, and did not differ significantly. Average fruit yields for methyl bromide plus chloropicrin were 305 (TIF) and 295 (STD) grams per plant, and did not differ significantly. Weed densities were not different between the films at the rates tested (data not shown).

2008 trial. Because application rates tested in 2007 were normal, the rates were sufficiently high to suppress most pathogens and weeds regardless of the film permeability. For this reason, in 2008 we chose to compare fumigant retention under the two films at a range of rates from low to high, to determine if TIF would

TABLE 1. Effect of totally impermeable (TIF) or standard (STD) film and 1,3-D plus chloropicrin (Pic) rate on survival of weeds in strawberry, 2008

\begin{tabular}{|c|c|c|c|}
\hline $\begin{array}{l}\text { Treatment } \\
\text { (pounds/acre) }\end{array}$ & TIF & STD & $\begin{array}{l}\text { TIF vs. } \\
\text { STD† }\end{array}$ \\
\hline \multicolumn{4}{|l|}{ Yellow nutsedge } \\
\hline Control (0) & 73.8 & 69.4 & ns \\
\hline 1,3-D + Pic (50) & 45.0 & 41.3 & ns \\
\hline 1,3-D + Pic (100) & 12.5 & 28.1 & $*$ \\
\hline 1,3-D + Pic (200) & 0.6 & 2.5 & ns \\
\hline $1,3-\mathrm{D}+\mathrm{Pic}(300)$ & 0.0 & 6.9 & ns \\
\hline $\begin{array}{l}\text { Methyl bromide + Pic } \\
(350)\end{array}$ & 0.6 & 3.1 & ns \\
\hline \multicolumn{4}{|l|}{ Common purslane } \\
\hline Control (0) & 47.8 & 53.3 & ns \\
\hline $1,3-D+P i c(50)$ & 22.8 & 53.0 & $* * *$ \\
\hline 1,3-D + Pic (100) & 1.0 & 1.5 & ns \\
\hline 1,3-D + Pic (200) & 1.5 & 1.0 & ns \\
\hline 1,3-D + Pic (300) & 0.0 & 0.0 & ns \\
\hline $\begin{array}{l}\text { Methyl bromide + Pic } \\
(350)\end{array}$ & 0.3 & 0.0 & ns \\
\hline \multicolumn{4}{|l|}{ Common chickweed } \\
\hline Control (0) & 37.8 & 47.8 & ns \\
\hline 1,3-D + Pic (50) & 11.3 & 22.8 & $* * *$ \\
\hline 1,3-D + Pic (100) & 0.3 & 1.0 & ns \\
\hline 1,3-D + Pic (200) & 0.3 & 1.5 & ns \\
\hline 1,3-D + Pic (300) & 0.0 & 0.0 & ns \\
\hline $\begin{array}{l}\text { Methyl bromide + Pic } \\
(350)\end{array}$ & 0.0 & 0.0 & ns \\
\hline \multicolumn{4}{|c|}{$\begin{array}{l}+^{*}=\text { significant at } P=0.05 ;{ }^{* * *}=\text { significant at } P=<0.001 ; \mathrm{ns}= \\
\text { not significantly different at } P=0.05 \text {. Asterisks show significant } \\
\text { difference in weed survival between TIF and STD films within rows. }\end{array}$} \\
\hline
\end{tabular}

improve retention and efficacy across that range.

At Salinas in 2008, 1,3-D plus chloropicrin concentrations in the 200-poundper-acre treatment were higher 24 hours post-application under TIF than under standard film (fig. 1B). The 1,3-D plus chloropicrin concentrations in the 300-pound-per-acre treatment were higher under TIF than under standard film at 8, 24, 48 and 96 hours after application. No injury to strawberry was observed when transplanted 4 weeks after fumigation (data not shown). Generally, there were no tarp effects on plant diameters except at the 1,3-D plus chloropicrin rate of 100 pounds per acre; TIF plants were 9.4 inches compared with 8.3 inches for standard-film plants $(P<0.0001)$.

Marketable fruit yields were higher with TIF than with standard film. The differences were significant in the 1,3-D plus chloropicrin treatments at 100 and 200 pounds per acre (fig. 2). There was a positive correlation between the 8-hour 1,3-D plus chloropicrin concentration and fullseason fruit yields for each film (standard $\left[\mathrm{r}^{2}=0.49, P=0.0001\right]$ and TIF $\left[\mathrm{r}^{2}=0.55, P\right.$ $=0.0001]$ ). The 8 -hour fumigant concentration accounted for $49 \%$ to $55 \%$ of yield variability in the standard and TIF treatments, respectively.

Weed densities were higher under standard film than under TIF. At 100 pounds per acre, 1,3-D plus chloropicrin applied under TIF had significantly fewer weeds than the same rate under standard film (fig. 3). The interaction between fumigant rate and film was significant for common chickweed $(P=0.0011)$ and common purslane $(P=0.0032)$, meaning that the survival of each of these two weeds was different under the two films. The interaction of yellow nutsedge rate by film was not significant $(P=0.20)$, indicating that nutsedge survival was similar under both films. However, we sought to describe the performance of TIF, therefore we evaluated nutsedge separately under both films. Yellow nutsedge tuber survival was less under TIF than standard film at 100 pounds per acre 1,3-D plus chloropicrin, but not at the other rates. Common purslane and common chickweed seed survival were lower under TIF than standard film at 50 pounds per acre 1,3-D plus chloropicrin (table 1). Little mallow and knotweed viability were similar under both films (data not shown).
Differences in weed control due to film type were only observed at the lower fumigant doses of 50 and 100 pounds per acre. This is likely due to the fact that TIF retained more fumigant than standard film, which resulted in a higher dose and lower weed seed survival under TIF than standard film (fig. 3). At application rates above 100 pounds per acre, the fumigant concentrations under both TIF and standard films were sufficiently high to kill weeds, so no differences were found between the films.

\section{Lower application rates}

Results of two trials conducted over 2 years indicate that TIF consistently held methyl bromide plus chloropicrin and 1,3-D plus chloropicrin (Telone C35 and Pic-Clor 60) at higher concentrations than standard film (fig. 1). At fumigant rates of 100 and 200 pounds per acre, strawberry fruit yields were higher and weed control was more complete where TIF was used, compared to standard film (figs. 2 and 3). This is likely due to the higher fumigant concentrations being held for a longer time under the TIF than under the morepermeable standard film, so that weeds and possibly soil pathogens (not measured) were more thoroughly controlled.

Drip-applied 1,3-D plus chloropicrin under standard film required at least 300 pounds per acre to provide fruit yields

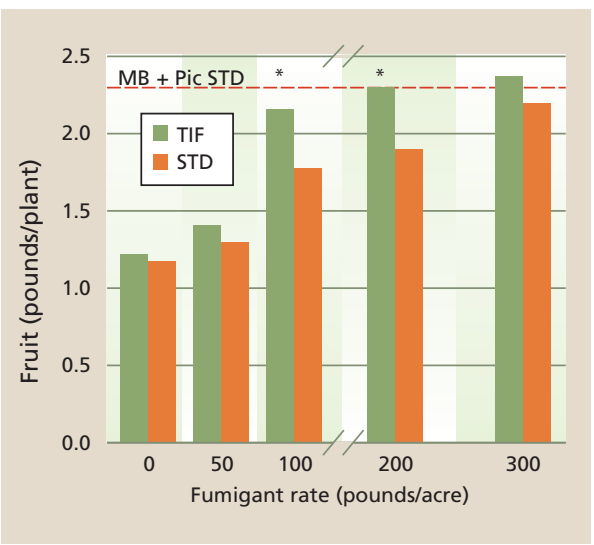

Fig. 2. Strawberry fruit yield per plant from March 30 to Oct. 30, 2009, in plots fumigated with 1,3-D plus chloropicrin using totally impermeable (TIF) or standard (STD) films. Reference standard yield is methyl bromide plus chloropicrin (MB + Pic) at 350 pounds per acre under STD, shown by the reference line at 2.31 pounds fruit per plant. Asterisks indicate that yield under TIF was significantly higher than under STD according to Duncan's multiple range test at $P=0.05$. 
comparable to methyl bromide plus chloropicrin (fig. 2). In contrast, 1,3-D pluschloropicrin drip-applied under TIF at 200 pounds per acre had fruit yields and weed control similar to methyl bromide plus chloropicrin, a $33 \%$ reduction in
1,3-D plus chloropicrin rate compared to standard film. Similarly, Ajwa et al. (2005) found that the rates of drip-applied chloropicrin required to produce strawberry yields similar to methyl bromide plus chloropicrin were 294 and 198 pounds per

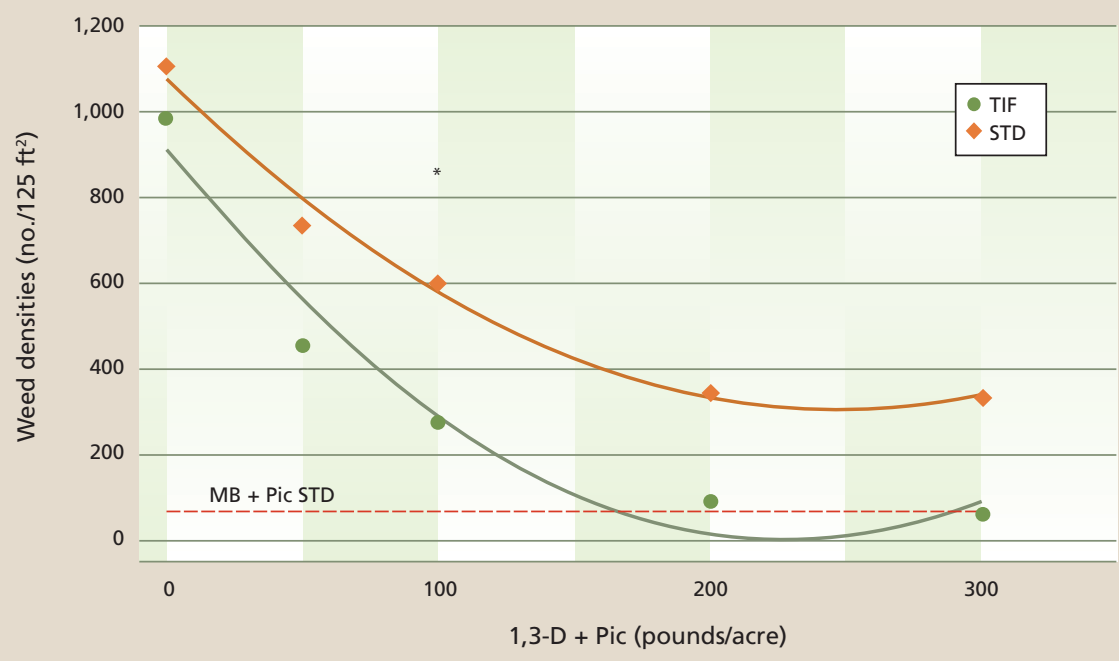

Fig. 3. Season-long weed densities per 125-square-foot sample area in plots previously fumigated with 1,3-D plus chloropicrin (Pic) using totally impermeable (TIF) or standard (STD) films. Lines are predicted values of nonlinear regression analysis using exponential decay function. The reference for weed control is methyl bromide plus chloropicrin under STD, shown by the reference line at 69.3 weeds per 125 square feet. Asterisk indicates that weed densities with TIF were significantly lower than with STD according to a Duncan's multiple range test at $P=0.05$.

\section{References}

Ajwa H. 2008. Testing film permeability to fumigants under laboratory and field conditions. In: Proc Ann Int Res Conf on MeBr Alternatives and Emission Reductions. Orlando, FL, Nov. 11-14, 2008. Abstr 35. www.mbao. org/2008/Proceedings/mbrpro08.html.

Ajwa HA, Shem-Tov S, Klose S, Fennimore S. 2005. Strawberry yield and weed control with shank and drip applied Midas. In: Proc Ann Int Res Conf on MeBr Alternatives and Emission Reductions. San Diego, CA, Oct. 31-Nov. 3, 2005. Abstr. 53.

Ajwa HA, Trout T, Mueller J, et al. 2002. Application of alternative fumigants through drip irrigation systems. Phytopathology 92:1349-55.

Carpenter J, Lynch L, Trout T. 2001. Township limits on 1,3-D will impact adjustment to methyl bromide phaseout. Cal Ag 55:12-8

[CDPR] California Department of Pesticide Regulation. 2008. Pesticide Use Report data. Sacramento, CA. www. cdpr.ca.gov/docs/pur/pur08rep/comrpt08.pdf. CDPR. 2010. Methyl lodide Controls are Stricter in California. Sacramento, CA. www.cdpr.ca.gov/docs/registration/ mei_pdfs/mei_chart_12-10.pdf.

CDPR. 2011. Approved Tarps for Products Containing Methyl lodide (Midas). Sacramento, CA. www.cdpr. ca.gov/docs/registration/mei_pdfs/tarp_list_approved. pdf.

Chellemi D, Mirusso JA. 2002. A new approach to fumigating soils under raised, plastic mulched beds. In: Proc Ann Int Res Conf on MeBr Alternatives and Emission Reductions. Orlando, FL, Nov. 6-8, 2002. Abstr 38.
Chow E. 2008. Properties of EVOH and TIF films for the reduction of fumigant dosage and VOC emission. Ann Int Res Conf on MeBr Alternatives and Emission Reductions. Orlando, FL, Nov. 11-14, 2008. Presentation 38. www. mbao.org/2008/Proceedings/mbrpro08.html.

De Cal A, Martinez-Treceňo A, Lopez-Aranda JM, Melgarejo P. 2004. Chemical alternatives to methyl bromide in Spanish strawberry nurseries. Plant Dis 88:210-4.

Desaeger J, Csinos A. 2005. Phytotoxicity associated with drip-applied 1,3-dichloropropene and chloropicrin in vegetables produced with plastic mulch. HortScience 40:700-6.

[ERS] Economic Research Service. 2009. U.S. strawberry industry. US Department of Agriculture, Washington, DC. http://usda.mannlib.cornell.edu/MannUsda/ viewDocumentInfo.do?documentID=1381.

Gamliel A, Grinstein A, Klein L, et al.1998. Permeability of plastic films to methyl bromide: Field study. Crop Prot 17:241-8.

Gao S. 2009. What to consider when emission reduction is required from soil fumigation. Calif. Plant and Soils Conference. p 48-54. http://ucanr.org/sites/calasa/ files/319.pdf.

Medina JJ, Miranda L, Romero F, et al. 2006. Seven years' work on alternatives to methyl bromide (MB) for strawberry production in Huelva (Spain). Acta Hort 708:205-10.

Minuto A, Gilardi G, Gullino ML, Garibaldi A. 1999. Reduced dosages of methyl bromide applied under gas-impermeable plastic films for controlling soilborne pathogens of vegetable crops. Crop Prot 18:365-71.

Nelson SD, Allen LH, Dickson DW, et al. 2001. Volatilization of 1,3-dichloropropene in Florida plasticulture and effects on fall squash production. J Am Soc Hort Sci 126:381-511. acre under standard and VIF, respectively, a $48 \%$ reduction in chloropicrin.

The recent registration of methyl iodide as a soil fumigant by the California Department of Pesticide Registration (CDPR) requires the use of impermeable films (CDPR 2010). Methyl iodide must be used with impermeable films as approved by CDPR, and TIF (Vaporsafe) is on the list of approved films (CDPR 2011). The results presented here further validate that TIF is effective at increasing fumigant retention and may ease some of the burdens of fumigant regulations on end-users, as well as ease concerns of the general public about exposure to fumigants.

S.A. Fennimore is Extension Specialist and Weed Scientist, and H.A. Ajwa is Extension Specialist and Soil Scientist, Department of Plant Sciences, UC Davis. Both are located at the USDA Agricultural Research Station, Salinas.

We are grateful for the financial support of Kuraray Americas and Mitsui Plastics for this project. We thank TriCal and Raven Industries for land, material and technical support; Jonathan Hunzie for making the fumigant applications; and J. Ben Weber for monitoring weed densities.

Porter I, Mattner S, Mann R, Gounder R. 2006. Strawberry nurseries: Summaries of alternatives and trials in different geographic regions. Acta Hort 708:187-92.

Santos BM, Gilreath JP, Motis TN. 2005. Managing nutsedge and stunt nematode in pepper with reduced methyl bromide plus chloropicrin rates under virtually impermeable films. HortTechnology 15:596-9.

Santos BM, Gilreath JP, Siham MN. 2007. Comparing fumigant retention of polyethylene mulches for nutsedge control in Florida spodosols. HortTechnology 17:308-11.

Segawa R. 2008. California regulatory issues for fumigants. Ann Int Res Conf on MeBr Alternatives and Emission Reductions. Orlando, FL, Nov. 11-14, 2008. Abstr 4. www.mbao.org/2008/004segawa.pdf.

[USDS] US Department of State. 2009. Methyl Bromide Critical Use Nomination for Preplant Soil Use for Strawberry Fruit Grown in Open Fields. Washington, DC. www. epa.gov/ozone/mbr/CUN2011/CUN2011Strawberry.pdf.

Wang D, Yates SR. 1998. Methyl bromide emission from fields partially covered with a high-density polyethylene and virtually impermeable film. Env Sci Tech 32:2515-8. Wang D, Yates SR, Ernst FF, et al. 1997. Reducing methyl bromide emission with a high barrier plastic film and reduced dosage. Env Sci Tech 31:3686-91.

Wang D, Yates SR, Gan J, Knuteson JA. 1999. Atmospheric volatilization of methyl bromide, 1,3-dichloropropene, and propargyl bromide through two plastic films: Transfer coefficient and temperature effect. Atmosph Env 33:401-7.

Wilhelm S, Paulus AO. 1980. How soil fumigation benefits the California strawberry industry. Plant Dis 64:264-70. 